\title{
Garrey Carruthers: Governor, Entrepreneur, University President
}

\author{
James Wetherbe (Texas Tech University)
}

KEYWORDS: Entrepreneurship, Management, Higher

Education.

Garrey Carruthers shares his remarkable journey of going from family farm boy to professor, to governor, to entrepreneur and to dean of business school and then president of New Mexico State University, where he has built the Arrowhead Center for Entrepreneurship.

Additional Search Terms: college presidents, academia, colleges and universities, business schools, entrepreneurship schools 